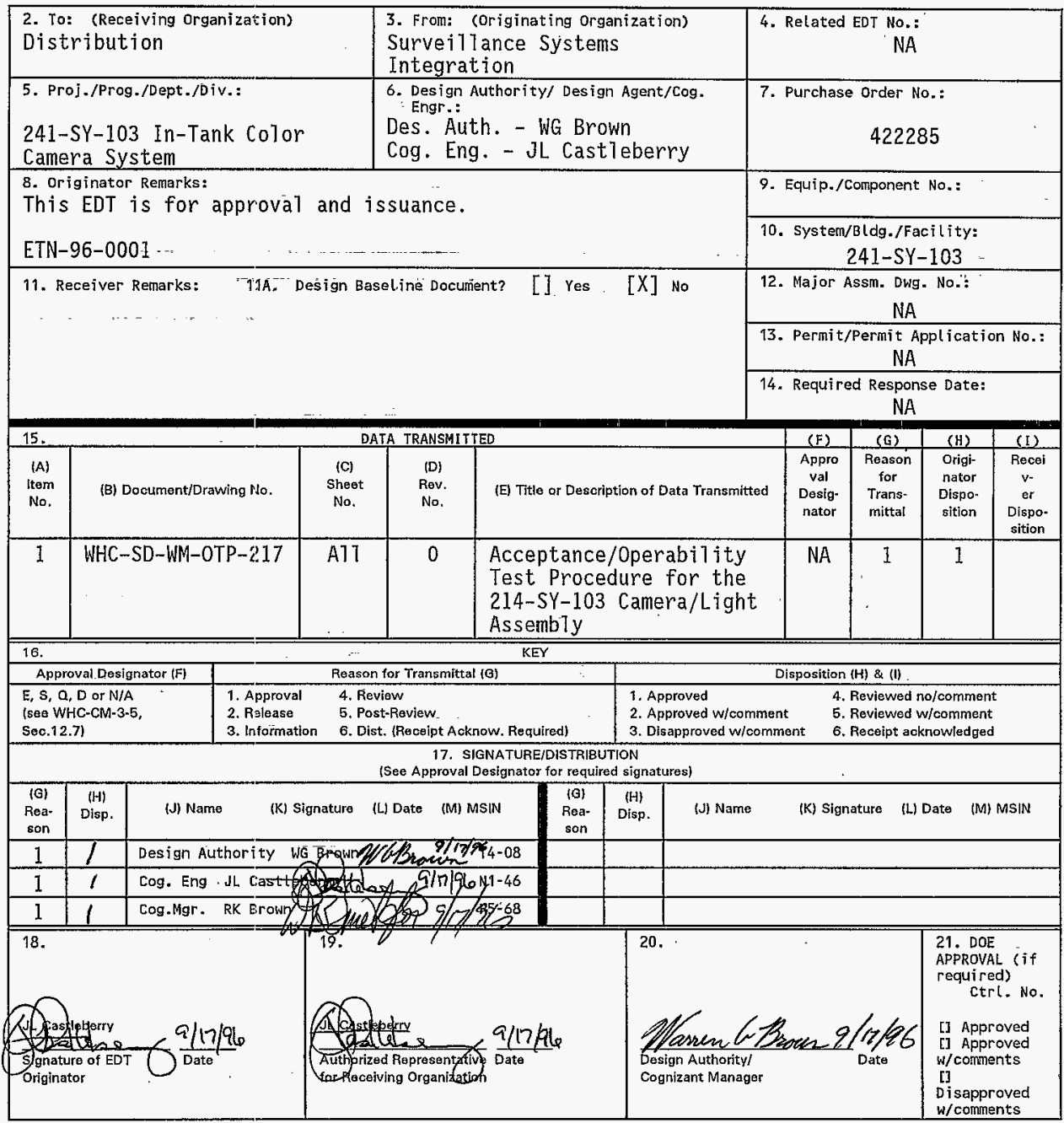

BD-7400-172-2(05/96)+GEF097 


\section{Acceptance/Operability Test Procedure for the 241-SY-103 Camera/Light Assembly}

JL Castleberry

Westinghouse Hanford Company, Richland, WA 99352

U.S. Department of Energy Contract DE-AC06-87RLL10930

EDT/ECN: 617448 UC:

Org Code: 74F40 Charge Code: N2241

B\&R Code: Total Pages: 89 kms $4 / 10 / 96$

Key Words: Camera/light assembly, camera, 241-SY-103

Abstract: This purpose of this procedure is to provide a documented means of verifying that a 11 the components of the 241-SY-103

Camera/Light Assembly operate properly when integrated with the existing control system.

TRADEMARK DISCLAIMER. Reference herein to any specific commercial product, process, or service by trade name, trademark, manufacturer, or otherwise, does not necessarily constitute or imply its endorsement, recormendation, or favoring by the United states Government or any agency thereof or its contractors or subcontractors.

Printed in the United States of America. To obtain copies of this document, contact: WHC/BCS Document Control Services, P.O. Box 1970, Mailstop H6-08, Richland WA 99352, Phone (509) 372-2420; Fax (509) 376-4989.
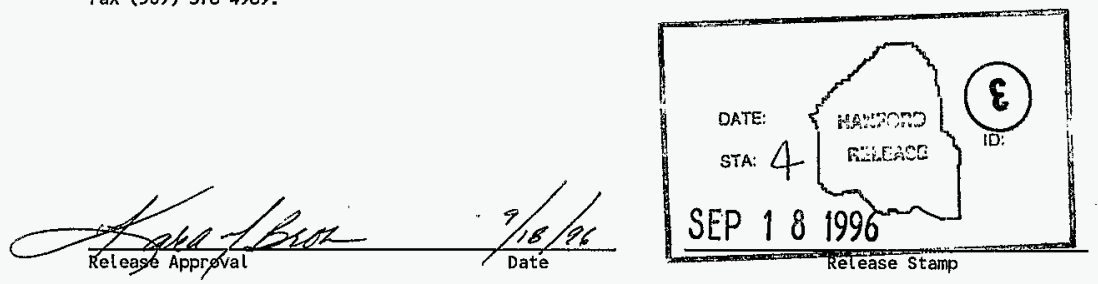

\section{Approved for Public Release}




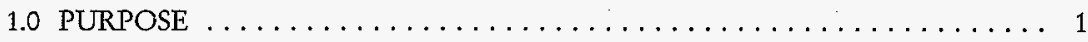

2.0 TEST OBJECTIVES $\ldots \ldots \ldots \ldots \ldots \ldots \ldots \ldots \ldots \ldots \ldots \ldots \ldots \ldots$

3.0 REFERENCES $\ldots \ldots \ldots \ldots \ldots \ldots \ldots \ldots \ldots \ldots \ldots \ldots \ldots \ldots \ldots \ldots \ldots \ldots \ldots \ldots$

4.0 RESPONSIBILITIES . . . . . . . . . . . . . . . . . . . 1

4.1 SURVEILLANCE SYSTEMS INTEGRATION $\ldots \ldots \ldots \ldots \ldots \ldots \ldots 1$

4.2 TEST WITNESSES $\ldots \ldots \ldots \ldots \ldots \ldots \ldots \ldots \ldots \ldots \ldots \ldots$

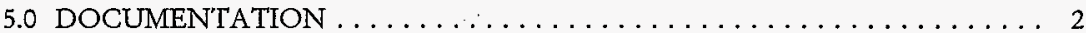

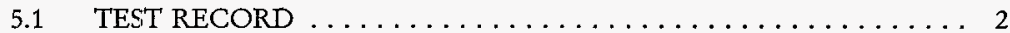

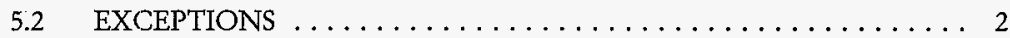

5.3 TEST EXECUTION RECORD $\ldots \ldots \ldots \ldots \ldots \ldots \ldots \ldots \ldots \ldots 2$

6.0 ACCEPTANCE/OPERABILITY TEST $\ldots \ldots \ldots \ldots \ldots \ldots \ldots \ldots \ldots, 2$

6.1 CAMERA AND PAN-AND-TILT ACCEPTANCE $\ldots \ldots \ldots \ldots \ldots 2$

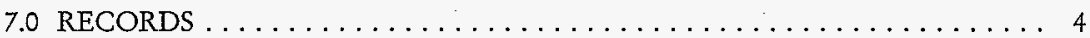

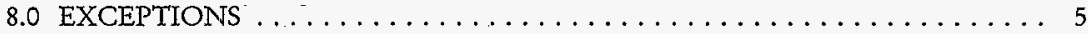

9.0 TEST EXECUTION RECORD $\ldots \ldots \ldots \ldots \ldots \ldots \ldots \ldots \ldots \ldots \ldots \ldots \ldots$

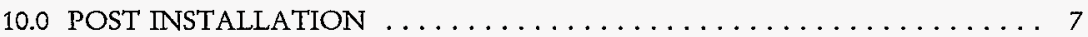
10.1 POST INSTALLATION TEST $\ldots \ldots \ldots \ldots \ldots \ldots \ldots \ldots \ldots$ 


\section{WHC-SD-WM-OTP-217 \\ REV. 0}

\subsection{PURPOSE}

This Acceptance/Operational Test Procedure (ATP/OTP) will document the satisfactory operation of the camera/light assembly destined for installation in tank 241-SY-103. The final acceptance of the camera/light assembly will be performed in the field. The existing purge panel and purge control panel will be used to control purging functions necessary to meet the ten volume exchange as required by NFPA Article 496. The existing safety interlock within the Camera Purge System (CPS) will be used to shut down power to the camera and pan-and-tilt inside the tank vapor space in the event there is a loss of cover gas pressure. The existing safety interlock has been acceptance/operational tested per WHC-SD-WM-OTP-161. The camera/light assembly will be controlled and powered by the existing remote control unit, local interface unit, and power supply that has been previously installed and tested per WHC-SD-WM-OTP-161.

\subsection{TEST OBJECTIVES}

The objective of this procedure is to demonstrate and document the acceptance and operability of the 241-SY-103 camera/light assembly and pan-and -tilt. The camera focus, zoom, and iris remote controls will be functionally tested. Also to be functionally tested is the camera frame store integration unit and camera lights. The pan-and-tilt unit will be tested for required ranges of motion.

\subsection{REFERENCES}

CVI

\#22587

\subsection{RESPONSIBILITIES}

\subsection{SURVEILLANCE SYSTEMS INTEGRATION}

A Surveillance Systems Integration (SSI) Test Engineer shall be responsible for the coordination, scheduling, performance and documentation of this test procedure.

\subsection{TEST WITNESSES}

Surveillance Systems Integration Test Engineer shall perform the function of test witness. All camera functions shall be witnessed, verified and approved with the SSI Test Engineers signature. 
WHC-SD-WM-OTP-217

REV. 0

\subsection{DOCUMENTATION}

\subsection{TEST RECORD}

Any personnel involved in the performance of this test including SSI Test Engineer shall fill out a line in Section 7.0 RECORDS.

Test results shall be recorded by the SSI Test Engineer. Unacceptable conditions or readings are to be referred to Section 8.0, EXCEPTIONS. A complete working copy of this procedure and all exception records generated shall be maintained as permanent records in accordance with WHC-CM-3-5.

\subsection{EXCEPTIONS}

Exceptions by step number, and other notes are to be recorded under Section 8.0. This section must be dispositioned (including the generation of any required ECNs) and signed off prior to final ATP/OTP acceptance. If no exceptions are encountered, this section shall be so noted and closed out with the required signature. During the performance of this test, errors in text may be encountered which require correction/adjustment to complete the test. The correction is to be noted in the ATP/OTP and listed as an exception in Section 8.0.

\subsection{TEST EXECUTION RECORD}

Approval of the ATP/OTP results shall be accepted by the SSI Test Engineer as indicated by signature in Section 9.0

\subsection{ACCEPTANCE/OPERABILITY TEST}

\subsection{CAMERA AND PAN-AND-TILT ACCEPTANCE}

NOTE: A purge cycle must be run to allow power to the camera, pan-and-tilt, and lights. Run 103-SY Camera Purge System (CPS) through a full purge cycle prior to testing.

6.1.1 Using remote pan-and-tilt controls, pan in the clockwise direction. Verify that the pan electronic break holds.

6.1.2 Pan in the opposite direction, and verify that the pan electronic break holds. Verify that the panning operation has covered approximately $360^{\circ}$. 
REV. 0

6.1.3 Tilt the camera to the extreme down position. Verify that the camera is pointing approximately straight down and that the electronic break holds.

6.1.4 Tilt camera up to the extreme upward position. Verify that the camera is approximately vertical and that the electronic break holds.

6.1.5 Using the remote camera zoom control, manipulate the zoom control to wide angle. Verify zoom moves towards wide when operated towards "wide".

6.1.6 Manipulate the zoom control to telephoto. Verify zoom moves towards telephoto when operated towards "tele".

6.1.7 Using the remote camera iris control, manipulate the iris control to open. Verify that the iris opens when operated towards "open".

6.1.8 Manipulate the iris control to close. Verify that the iris closes when operated towards "close".

6.1.9 Using the remote camera focus control, manipulate the focus control to far. Verify that the focus adjusts to far when operated towards "far".

6.1.10 Manipulate the focus control to near. Verify that the focus adjusts to near when operated towards "near".

6.1.11 Verify that the frame store integrator is operational.

6.1.12 Verify that there is a color image present on the video camera system monitor located in the 241-SY-101/103 Video Shack.

6.1.13 Manipulate individual ballast switches of the camera light ballast box located on the purge panel to the "ON" position. Each ballast should be switched to the "ON" position in 30 second intervals. Verify that all six lights of the camera/light assembly are operational.

6.1.14 Adjust pressure regulator PR-1(PCV-3157C) to restrict flow of cover gas through camera/light assembly. Verify that interlock relay shuts down power when cover gas pressure reads $10 \mathrm{in.} \mathrm{w.g.} \mathrm{on} \mathrm{the} \mathrm{Pressure} \mathrm{Indicating}$ Transmitter (PIT-3156C) located in the purge panel.

6.1.15 Section 6.1 is complete SSI Test Engineer 


\section{WHC-SD-WM-OTP-217 \\ REV. 0}

\subsection{RECORDS}

\section{TEST WITNESSES}

Test Personnel Attendance Sign In:

Test Engineer/Date

Cognizant Engineer/Date

Other Personnel Present:

Print Name

Signature

Position

Date

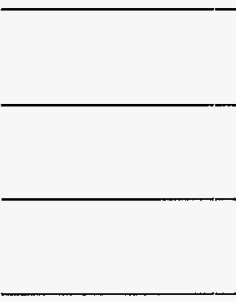




\section{WHC-SD-WM-OTP-217}

REV. 0

\subsection{EXCEPTIONS}

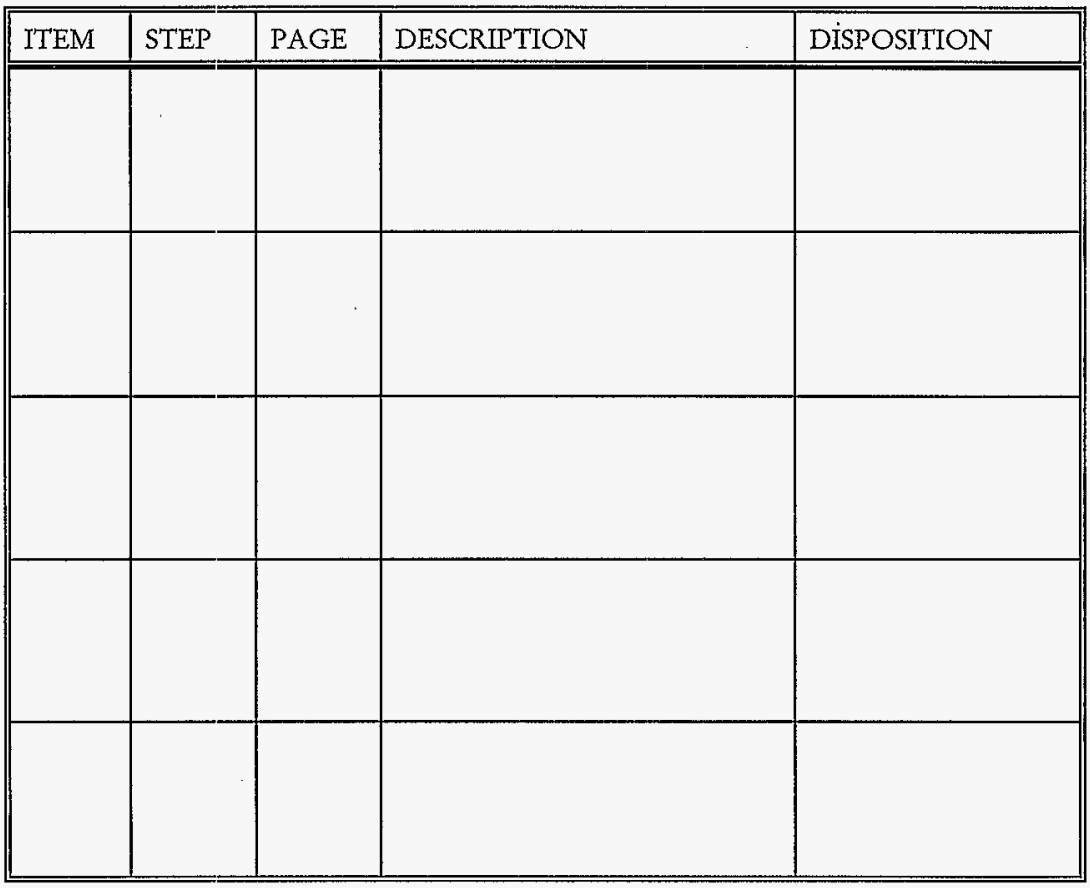

TEST APPROVED WITH EXCEPTIONS:

SSI Test Engineer

Date 
WHC-SD-WM-OTP-217

REV. 0

9.0 TEST EXECUTION RECORD

\begin{tabular}{||l|l|l||}
\hline $\begin{array}{l}\text { REFERENCE } \\
\text { SECTION }\end{array}$ & ACCEPT/REJECT & REMARKS \\
\hline \hline & & \\
\hline & & \\
\hline & & \\
\hline & & \\
\hline
\end{tabular}

SSI Test Engineer/Date 


\section{WHC-SD-WM-OTP-217}

REV. 0

\subsection{POST INSTALLATION}

\subsection{POST INSTALLATION TEST}

Repeat section 6.1of this procedure to ensure that the Video Camera System is operating satisfactorily after installation of the camera into the $20^{\mathrm{n}}$ opening of the camera adaptor flange located in riser $5 \mathrm{~B}$. Any discrepancies found with the Video Camera System in accordance with this section of the ATP/OTP shall be noted below. Section 10.0 shall not be complete with SSI Test Engineers Signature.

Date

SSI Test Engineer 